\title{
Science and Policy
}

\section{Science for Environment Policy - A Service from the European Commission DG Environment News Alert Service}

\author{
DOI: http://dx.doi.org/10.1065/jss2006.06.160
}

The European Commission, DG Environment, has established the 'News Alert Service', available at the Commission's website $<\underline{\text { http:// }}$ ec.europa.eu/environment/integration/research_alert_en.htm $>$, to reinforce the links between science and policy.

The aim of this service is to provide new scientific results in the field of top priority environmental issues. Addressed to policy-makers and the wider public, this service is designed to promote - in a user-friendly form and a comprehensive, non-technical language the integration of the environmental science into management and decision-making practices.

The 'Science for Environment Policy' News Alert Service offers a wide array of articles covering the most recent results of completed or on-going EU funded projects as well as other research initiatives implemented at international, national and regional levels. Most of the featured articles are drawn from scientific publications where research results have first been peer-reviewed for their legitimacy.

The sources for this service are provided by the specialised staff of the contractor as well as by EC officials. Opinions expressed in the flash articles do not necessarily reflect those of the European Commission.

The following themes - which cover the main themes of the EU's Environment Action Programme and DG Environment's policy priorities - are provided (the articles are sorted by theme or by date):

$\begin{array}{ll}\text { - Agriculture } & \text { - Noise } \\ \text { - Air pollution } & \text { - Risk Assessment } \\ \text { - Bodiversity } & \text { - Soil } \\ \text { - Biotechnology } & \text { - Sustainable Consumption and } \\ \text { - Chemicals } & \text { Production } \\ \text { - Climate Change \& Energy } & \text { - Sustainable Development and } \\ \text { - Environment Technologies } & \text { - Sustainable Mobility } \\ \text { - Forests } & \text { - Urban Environment } \\ \text { - Health } & \text { - Waste } \\ \text { - Land use } & \text { - Water }\end{array}$

The Newsalert articles are weekly disseminated by e-mail and completely free of charge.

'Science for Environment Policy' is edited by 'Bio Intelligence Service' on behalf of the Directorate General Environment of the European Commission: Science for Environment Policy, c/o BIO Intelligence Service, 1 rue Berthelot, 94200 Ivry-sur-Seine, France (Tel: + 331562028 98). For additional information on the service, contact $<$ science-env-policy@biois.com?subject=Contact $>$.

Subscribe for free

$<$ mailto:science-env-policy@biois.com?subject= SUBSCRIBE\%20weekly\%20NewsAlert>

\section{U.S. Environmental Protection Agency Contaminated Sediment Remediation Guidance for Hazardous Waste Sites (2005)}

\section{http://www.epa.gov/superfund/resources/sediment/guidance.htm}

In December 2005, EPAs Office of Solid Waste and Emergency Response issued the final Contaminated Sediment Remediation Guidance for Hazardous Waste Sites. The guidance is designed to assist EPA staff managing sediment sites by providing a thorough overview of methods that can be used to reduce risk caused by contaminated sediment.

The guidance encourages project managers to consider a number of factors during cleanup of contaminated sediment, such as:

- Identifying and controlling the sources of sediment contamination and identifying the pathways of contaminant exposure, prior to cleanup;

- Using a technical team approach and involving the community and other stakeholders throughout the cleanup process;

- Considering all three major approaches to management of contaminated sediment (monitored natural recovery, in-situ capping, and dredging) and considering alternatives which combine approaches;

- Validating models used to support sediment decisions and considering model uncertainty and sensitivity;

- Considering how contaminated sediment alternatives manage or reduce risks, including consideration of residual risks; and

- Monitoring the effectiveness of remedies at contaminated sediment sites.

\section{From the contents:}

Chapter 2, Remedy Investigation Considerations, introduces investigation issues unique to the sediment environment, including those related to characterizing the site, developing conceptual site models, understanding current and future watershed conditions, controlling sources, and developing cleanup goals.

Chapter 3, Feasibility Study Considerations, supplements existing EPA guidance by offering sediment-specific guidance about developing alternatives, applying the NCP remedy selection criteria, identifying applicable or relevant and appropriate requirements (ARARs), evaluating effectiveness and permanence, estimating cost, and using institutional controls.

Chapter 4, Monitored Natural Recovery, describes the natural processes that should be considered when evaluating MNR as a remedy, and briefly discusses enhanced natural recovery through thin-layer placement of sand or other material.

Chapter 5, In-Situ Capping, summarizes the major capping technologies and describes the site conditions that are important to understand in evaluating the feasibility and effectiveness of in-situ capping.

Chapter 6, Dredging and Excavation, describes dredging technologies (conducted under water) and excavation technologies (typically conducted after water is diverted or drained).

Chapter 7, Remedy Selection Considerations, discusses risk management decision making, the NCP's remedy selection framework, including considering sediment remedies and comparing net risk reduction, considering alternatives that include institutional controls, and considering a 'noaction' decision.

Chapter 8, Remedial Action and Long-Term Monitoring, provides a recommended approach to developing an effective monitoring plan at contaminated sediment sites.

Further information may be found by contacting Leah Evison at evison.leah@epa.gov or (703) 603-9022 or Stephen Ells at ells.steve@epa.gov or (703) 603-8822 